Relations industrielles

Industrial Relations

\title{
Our Fifth Year
}

\section{The Editors}

Volume 5, numéro 1, septembre-octobre 1949

URI : https://id.erudit.org/iderudit/1023270ar

DOI : https://doi.org/10.7202/1023270ar

Aller au sommaire du numéro

Éditeur(s)

Département des relations industrielles de l’Université Laval

ISSN

0034-379X (imprimé)

1703-8138 (numérique)

Découvrir la revue

Citer cet article

The Editors (1949). Our Fifth Year. Relations industrielles / Industrial Relations, 5(1), 1-1. https://doi.org/10.7202/1023270ar

Tous droits réservés @ C Département des relations industrielles de l’Université Laval, 1949
Ce document est protégé par la loi sur le droit d'auteur. L'utilisation des services d'Érudit (y compris la reproduction) est assujettie à sa politique d'utilisation que vous pouvez consulter en ligne.

https://apropos.erudit.org/fr/usagers/politique-dutilisation/ 


\section{Industrial Relations Bulletin}

\section{OUR FIFTH YEAR}

As with so many productions called to fill a disinterested educative and social function the "Industrial Relations Bulletin» of Laval University began with difficulty and has progressed labouriously. The fact that, in spite of all, it has succeeded in sticking it out for four years bears eloquent witness to its vitality and to its growing usefulness. In the course of this period, as a matter of fact, our readers have been kind enough to say that is has already rendered appreciable services.

Strong in the encouragement received, the Bulletin commences its fifth year in a new dress and with an increased determination to carry out its mission more and more adequately. Up until now it has been presented to the reader under a rather sober exterior. With the hope of pleasing and of giving to the publication an appearance more in keeping with the dynamism of its ideas and the requirements of modern publicity, the Département des relations industrielles has decided to rejuvenate and brighten up its presentation by adopting an appropriate cover.

In order to give more attention to the choice of articles and to enlarge the circle of contributors while giving special care to the technical preparation of the Bulletin, an editorial committee has been formed as follows: M. l'abbé Gérard Dion, director, M. Gaston Cholette, Literary Editor, MM. Jean Gagné and Denys Dion, advisors. This committee has already brought about improvements which will increase the value and the influence of the Bulletin. Articles on reviews are inaugurated with this number. In the course of the next months other items will be added - reports on research, articles on books, a section devoted to information, a space reserved for the remarks of readers, etc.

Most of the changes adopted will result in making the Bulletin a more efficient means of information. This orientation in no way indicates that doctrinal articles will be less numerous or that the space reserved for them will be less considerable. The Bulletin would betray its mission if it acted so because its chief aim is to interpret the social doctrine of the Church and to comment in the light of the pontifical texts, upon the principal events which arise in the world of labor relations. Its doctrinal character will not then in any way be diminished and may even be accentuated.

Two years ago, most of the normative articles bore on the reform of structure in the enterprise. In view of the great interest they aroused and the reactions they produced, other articles in the same subject will be prepared in the course of the year which now commences. If the Bulletin attaches so much importance to this theme it is because it appears as one of the chief things to which it is important to draw attention and provoke serious consideration. And this, not only because of its complexity, but above all because of the need of urgency in its application for the Christian renewal of society.

The Editors hope that the readers will be satisfied with these changes and show their appreciation by reading the Bulletin attentively and securing it a wider circulation.

The EdrTors

Readers will please note that the first number of each Volume of the Bulletin will no longer be published in September but in October. Thus the present issue is the first one of Volume 5. 